Abstracta Iranica Abstracta Iranica

Revue bibliographique pour le domaine irano-aryen

Volume 24 | 2003

Comptes rendus des publications de 2001

\title{
Afḡānestān dar rāh-e āzādi [Afghanistan on the Road of Freedom]. Pishawar, 1999, 392 p.
}

\section{Tchanguiz Pahlavan}

\section{(2) OpenEdition}

1 Journals

Édition électronique

URL : http://journals.openedition.org/abstractairanica/34925

DOI : 10.4000/abstractairanica.34925

ISSN : 1961-960X

\section{Éditeur :}

CNRS (UMR 7528 Mondes iraniens et indiens), Éditions de l'IFRI

\section{Édition imprimée}

Date de publication : 15 mai 2003

ISSN : 0240-8910

\section{Référence électronique}

Tchanguiz Pahlavan, « Afǵānestān dar rāh-e āzādī [Afghanistan on the Road of Freedom]. Pishawar, 1999, 392 p. », Abstracta Iranica [En ligne], Volume $24 \mid$ 2003, document 340, mis en ligne le 05 janvier 2010, consulté le 25 septembre 2020. URL : http://journals.openedition.org/abstractairanica/34925 ; DOI : https://doi.org/10.4000/abstractairanica.34925

Ce document a été généré automatiquement le 25 septembre 2020.

Tous droits réservés 


\title{
Afḡānestān dar rāh-e āzādi [Afghanistan on the Road of Freedom]. Pishawar, 1999, 392 p.
}

\author{
Tchanguiz Pahlavan
}

1 From the introduction of this book written by Dr. Habibollah Farahmand we learn that the articles presented in this volume were collected by the late Najibollāh who died in USA in 1965.

2 Most of the articles reprinted in this book are from the famous Afghan historian Ahmad Ali Kohzad. The rest are from Ghobar, also a well known historian of Afghanistan, M. Hashem Meyvandal, M. Sadigh Farhang (well known historian), Yusefzai, A. Dawi, A. Binawa and M. Najim Arya.

3 These articles deal with some of the aspects of the history of Afghanistan especially with regard to the relations with Pakistan and the problems concerning the Durand Line. With this book we also learn the way some of the Afghanistan's historians looked at the influences of the colonial period and contemporary history of this country. The last article of the book is devoted to Afghanistan and Iran written by A. A. Kohzad. In this article Kohzad tries to show the historical and cultural ties which could be of interest for the scholars of the common civilization in this region.

\section{INDEX}

Thèmes : 13.2. Afghanistan 


\section{AUTEURS}

TCHANGUIZ PAHLAVAN

Berlin 